\title{
Conservation of crisp lettuce in different post-harvest storage conditions ${ }^{1}$
}

\author{
Mariana Izabel Schvambach ${ }^{*}$ (D), Bruna Vargas Andriolli², Priscila Fernandes de Souza ${ }^{2}$, \\ Jorge Luiz Barcelos Oliveira ${ }^{3}$, Rosete Pescador ${ }^{4}$
}

\begin{abstract}
The objective of this work was to evaluate the post-harvest quality and the final storage time of the hydroponic crisp lettuce 'Brida', conditioned in different types of plastic packaging and environments. The statistical design was a completely randomized $3 \times 2$ factorial design, with 3 types of packages (control (without plastic packaging), perforated plastic packaging and closed plastic packaging) and 2 types of environments refrigerated $\left( \pm 5^{\circ} \mathrm{C}\right)$ and non-refrigerated $\left( \pm 23^{\circ} \mathrm{C}\right)$. Fresh leaf weight loss, relative SPAD content, total soluble solids content (TSS), pH, total titratable acidity (TTA), chlorophyll a and b, carotenoids and final storage time were measured. There was a decrease in the parameters of fresh mass, acidity, total soluble solids, and relative content of SPAD chlorophyll in refrigerated lettuce compared to uncooled. The use of packages also influenced post-harvest quality and closed packs resulted in lower values. It is concluded that the post-harvest quality of lettuce is better when they are refrigerated and packed in sealed packages.
\end{abstract}

Keywords: Lactuca sativa L.; plastic packages; environments.

\section{INTRODUCTION}

Lettuce (Lactuca sativa L.) is the most consumed leafy vegetable in Brazil, being one of the basic components of salads prepared both in homes and in commercial establishments (Moretti \& Mattos, 2006).

Among the lettuce varieties, crisp lettuce has stood out among the producers. The lettuce originates from the Mediterranean and was one of the first vegetables to be cultivated by man. It is currently cropped all over the country and can be grown throughout the year, both in soil and in hydroponic systems. Moreover, this leafy vegetable presents a better adaptation to the summer crop, as much as its resistance to early tillage and diseases, greater ease for transportation, longer shelf life and better texture for consumers (Rodrigues et al., 2007; Meirelles, 1998; Soares, 2002).
Despite the great consumption, the leafy vegetables in general present high fragility and may deteriorate in few days after the harvest. Therefore, immediate consumption or use of post-harvest conservation techniques is necessary (Finger et al., 1999). Among the techniques to increase the shelf life and presentation of the product to the consumer, packing vegetables in suitable packages and storage under refrigeration is also important (Rosa, 2002). The maintenance of the vegetables at a great temperature for preservation, from the harvest to the consumption, reduces the respiratory rate as well as the microbiological and enzymatic activity, allowing a better post-harvest life of the vegetable (Rickman et al., 2007).

Another important factor for leafy vegetables preservation is the use of suitable packaging. The packaging is used in harvest, transport and retail of

\footnotetext{
Subitted on December $5^{\text {th }}, 2018$ and accepted on June $8^{\text {th }}, 2020$.

'This work is part of the first author's course work.

${ }^{2}$ Universidade Federal de Santa Catarina, Florianópolis, Santa Catarina, Brazil. marianais2010@hotmail.com; bruandriolli@hotmail.com; souza.fernandes.p@gmail.com

${ }^{3}$ Universidade Federal de Santa Catarina, Departamento de Engenharia Rural, Florianópolis, Santa Catarina, Brazil. j.barcelos@ufsc.br

${ }^{4}$ Universidade Federal de Santa Catarina, Departamento de Fitotecnia, Florianópolis, Santa Catarina, Brazil.rosete.pescador@ufsc.br

*Corresponding author: marianais2010@ hotmail.com
}

Rev. Ceres, Viçosa, v. 67, n.4, p. 247-250, jul/aug, 2020 
vegetables. Its main functions are to avoid mechanical damages and to group products in suitable units for market and handling (Shepherd, 1993). According to Ballou (2001), adequate packaging is one of the main factors to avoid post-harvest losses.

To evaluate the efficiency of post-harvest conservation, the awareness of physiological parameters is extremely important, such as physical, chemical and sensorial characteristics.

According to Bezerra (2003) the quality of a food product is a difficult point to define, since it varies with its type and its purpose. For the consumer, some appearance characteristics such as size, shape, color, absence of spots, texture, taste, scent and nutritional value are the main quality attributes required. The postharvest quality of leafy vegetables is evaluated especially for the contents of total soluble solids, $\mathrm{pH}$ and total titratable acidity (Chitarra, 1994). In this context, researches aimed at postharvest conservation in vegetables are very important, in order to minimize postharvest losses and avoid food waste.

The purpose of this work was to evaluate the postharvest quality and the final storage time of the hydroponic crisp lettuce (Brida cultivar), packed in plastic packaging with and without perforations and storage at \pm $5{ }^{\circ} \mathrm{C}$ and $\pm 23{ }^{\circ} \mathrm{C}$.

\section{MATERIAL AND METHODS}

The experiment was conducted at the Agricultural Sciences Center of the Federal University of Santa Catarina, located in highway Admar Gonzaga, 1346, Itacorubi, Florianópolis, with humid subtropical climate (Cfa), according to the climatic classification of Koppen, from January 16 to February 5, 2018.

The lettuce leaves used in the experiment were produced in Hydroponics Laboratory (LabHidro) of the Department of Agricultural Engineering in Agricultural Science Center (CCA), in Florianópolis - SC, in summer crop condition.

Curly lettuce (Lactuca sativa L.) 'Brida' were harvested and selected at the development stage corresponding to commercial harvest, 40 days after sowing. Plants were fully harvested at 8:00 AM for further evaluation of post-harvest conservation.

After harvesting the lettuces, they were taken to the Phytotron Laboratory of the Department of Plant Science of UFSC, which were collected five samples to be evaluated on the harvest day (time zero) while the other plants were stored and prepared according to each treatment.

The plastic packaging used was made of polypropylene material, which is a perforated plastic in a conical shape with a size of $20 \mathrm{~cm}$ by $40 \mathrm{~cm}$ and thickness of 0.005 and a transparent bag with a size of $20 \mathrm{~cm}$ by 30 $\mathrm{cm}$ and thickness of $0.012 \mathrm{~mm}$. In cold environment, a domestic refrigerator with a temperature of $\pm 5{ }^{\circ} \mathrm{C}$ and relative humidity of 10 to $15 \%$. In the non-refrigerated environment, the samples were kept at an ambient temperature of $\pm 23{ }^{\circ} \mathrm{C}$, without controlling the relative humidity.

The statistical design used in the experiment was completely randomized in a $3 \times 2$ factorial scheme, with six treatments and four replications, totalizing 24 plots. Each experimental unit was composed of ten lettuce leaves that were randomly chosen. The treatments consisted of: three types of packaging (Control: without plastic packaging, perforated plastic packaging and closed plastic packaging) and two types of environments at $\pm 5{ }^{\circ} \mathrm{C}$ (refrigerated) and $\pm 23^{\circ} \mathrm{C}$ (non-refrigerated).

The characteristics analyzed during the experiment were:

Fresh initial and final mass: all lettuce leaf samples were weighed in a METRA analytical balance to later calculate the loss of leafy water.

Loss of fresh mass during storage: It was determined from the equation

$P M F=(M F i-M F f \times 100) \div M F i$

in which, PMF: loss of fresh mass (\%); MFi: initial fresh mass and MFf: final fresh mass. Soon after, the results were transformed into percentage of fresh mass.

Relative content of chlorophyll SPAD: This was determined by direct reading with the aid of a chlorophyll meter equipment, model Minolta SPAD-502, in each sample five leaves of lettuce were chosen to perform an average between the values collected per leaf.

Total soluble solids content: The content was determined by a refractometer, using $1.0 \mathrm{~g}$ of lettuce leaves macerated in crucible and diluted in $1.0 \mathrm{~mL}$ of distilled water. A fieldspecific digital refractometer was used to perform the brixgrade for reading the samples, with a reading range 0 Brix of $0 \mathrm{H} \approx 32 \%$ and accuracy of 0.2 . Before reading each sample, the refractometer was calibrated with distilled water and after the calibration a drop of each sample was placed on the surface of the prism, reading directly and the results were expressed in the brix according to the Association of Official Analytical Chemistry (AOAC, 2002).

$\boldsymbol{p H}$ : The $\mathrm{pH}$ was determined through measurements made using a pHmeter digital bench branded Ion PHB-500, from the maceration of $1.0 \mathrm{~g}$ of lettuce leaf diluted in $30 \mathrm{~mL}$ of distilled water according to the AOAC (2002). 
Titratable total acidity (TTA): It was determined by a titrameter, using $1.0 \mathrm{~g}$ sample of lettuce leaf macerated with $75 \mathrm{~mL}$ of distilled water with a phenolphthalein indicator drop and titration with 0.1 of sodium hydroxide $(\mathrm{NaOH})$ until reaching the turning point of the phenolphthalein indicator, changing to pink color (AOAC, 2002). The results were determined from the equation:

Malic acid $(g \backslash 100 m l)=V \times M \times 75 \times 100 \div 1000 \times v$

In which $\mathrm{V}=$ volume of $0.1 \mathrm{M} \mathrm{NaOH}$ spent in the titration; $\mathrm{M}=$ molarity of $\mathrm{NaOH}$ solution $(0.1) ; \mathrm{v}=$ volume of the sample used in the solution. The results were expressed as percent of malic acid.

Quantification of pigments (chlorophyll $a$ and $b$ and carotenoids): $1.0 \mathrm{~g}$ of each sample was macerated with 10 $\mathrm{mL}$ of acetone, and then filtered. The final volume was adjusted to $25 \mathrm{~mL}$ (Bruinsma, 1963). The samples remained in the dark for 15 minutes (wrapped in foil). Therefore, the absorbance of the samples was determined by spectrophotometry at wavelengths 663,647 and $470 \mathrm{~nm}$. The pigment contents were obtained from the equation proposed by (Lichtenthaler, 1987):

$$
\begin{aligned}
& \text { Cla }=11,24[\text { A663] - 2,04 [A647] (Chlorophyll a }) \\
& C l b=20,13[\text { A647] }-19[\text { A663] (Chlorophyll b) } \\
& C+X=(1000[\text { A470] - 1,90 Ca }=63,14 C b \div 214 \\
& (\text { Carotenoids })
\end{aligned}
$$

The results were expressed in $\mu \mathrm{g} . \mathrm{g}^{-1} \mathrm{FM}$.

Final storage time: For the final storage time, tolerance limits were established for the general aspects of lettuce leaves when they were: wilted, yellowed or with signs of deterioration, and they were unfit for consumption. The parameters used for the final time of storage were: wilting, yellowing and the appearance of some signs of deterioration.

Statistical analysis: Data were submitted to analysis of variance (ANOVA) and the rates were compared by Tukey test at $5 \%$ probability. In relation to the variable loss of fresh mass and carotenoids, the data were transformed into $\log$. However, the transformation of variable fresh weight loss did not meet the analysis of variance, as the better option was to use the descriptive statistics for this variable.

\section{RESULTS AND DISCUSSION}

The loss of fresh mass in lettuce leaves presented great variation among the treatments (Figure 1). There were higher losses in control treatment (without plastic packaging) without and with refrigeration, about $53.6 \%$ and $43.7 \%$, respectively. The loss of fresh mass comprises the reduction of fresh weight of the product over time, related to the movement of water in the product after its harvest. Due to this intense transpiration process, a deficit occurs and the product ends up losing water to the environment causing a water stress. This water stress has as characteristics the loss of turgidity and reduction in the fresh weight of the samples (Chitarra \& Chitarra, 2005). The loss of mass has several effects on the physiology of plant tissues, and it can anticipate maturation and senescence of the leaves (Carvalho \& Lima, 2002).

The initial symptoms of excessive water loss are leaf wilting and wrinkling, which may accelerate deterioration due to increased catabolic source reactions (Finger \& Vieira, 1997). In contrast, the leaves stored in closed plastic packaging without and with refrigeration presented low loss of fresh mass, about $7.5 \%$ and $3.5 \%$, respectively. These results demonstrate the importance of using packaging in storage. According to Chitarra \& Chitarra (2005), the packages allow the selective exchange of gases from the interior with the external atmosphere, causing the elevation of carbon dioxide level and decrease of oxygen, with the aid of product respiration. However, refrigeration slows the maturation, respiratory activity and decreases the heat production of the samples, showing efficiency in relation to the loss of fresh leaf mass and prolonging the commercial life of these products (Chitarra \& Chitarra, 1990).

Similar results were found by Oliveira et al. (2015) in a storage of cilantro at temperature of $\pm 5^{\circ} \mathrm{C}$, in which the low temperature delayed the loss of water, due the reduction of water potential gradient between the environment and the leaves, showing the beneficial effect of the reduction of temperature in the prolongation of the postharvest life of vegetables.

According to the results, it was verified that there was no significant interaction between the packages and the environment for all the variables studied, except for the titratable total acidity, $\mathrm{pH}$ and carotenoid content (Table 1). For the variable soluble solids, there were significant differences between packages, and for the variable relative content of chlorophyll SPAD, significant differences were found among the environment. There were no significant differences for the chlorophyll a and b variables (Table 1 ).

The titratable total acidity variable (Table 2) on the harvest day was $0.00656 \%$. When the treatments were compared regarding titratable total acidity at harvest, an increase in acidity was observed for all treatments except for those with closed plastic packaging with and without refrigeration (Table 2). It was also observed that only these treatments presented statistical differences among treatments, and the treatment of closed plastic packaging with refrigeration showed the lowest percentage of titratable total acidity (Table 2). This decrease in acid 
content is related to the fact that, after harvesting and during storage, the concentration of organic acids usually declines because of its use as a substrate in respiration or for transformation into sugars (Chitarra \& Chitarra, 2005). The total titratable acidity is a parameter involved with the state of conservation of the product. Besides influencing the sensorial characteristics of foods, it is an indicative of acid or sour taste in vegetables, except for vegetables with low acidity. In this case, they are more susceptible to deterioration (Paschoalino, 1997). Thus, the treatment of closed plastic packaging with refrigeration presented a lower acidity in relation to the other treatments, becoming more susceptible to deterioration. Therefore, the lower consumption of organic acids presented in this treatment can be justified by the consumption of the vegetable tissue itself, in attempt to maintain its initial state of quality (Rinaldi et al., 2005).
The $\mathrm{pH}$ (Table 2) on the harvest day was 5.94. When treatments were compared to the $\mathrm{pH}$ value on the harvest day, a decrease was observed for all treatments except for the treatment of closed plastic packaging with refrigeration (Table 2). It was also observed that only this treatment presented statistical differences compared to other treatments, and the treatment of closed plastic packaging with refrigeration presented a higher $\mathrm{pH}$ value, which is a lower acidity, while the other treatments showed a higher acidity which influences a bitter taste in leaves, presenting an undesirable flavor to the consumers (Table 2). Similar results were found in the work of Marin et al. (2010) when evaluating the active packaging for fresh lettuce (Lactuca sativa L.), due to the high respiration rate of the product that consumed the organic acids, causing $\mathrm{pH}$ increase.

For the carotenoid variable (Table 2), the harvest day was $0.1866 \mu \mathrm{g} \cdot \mathrm{g}^{-1} \mathrm{MF}$. When treatments were compared to the carotenoid value at harvest, a decrease of carotenoids

\section{Loss of fresh mass}

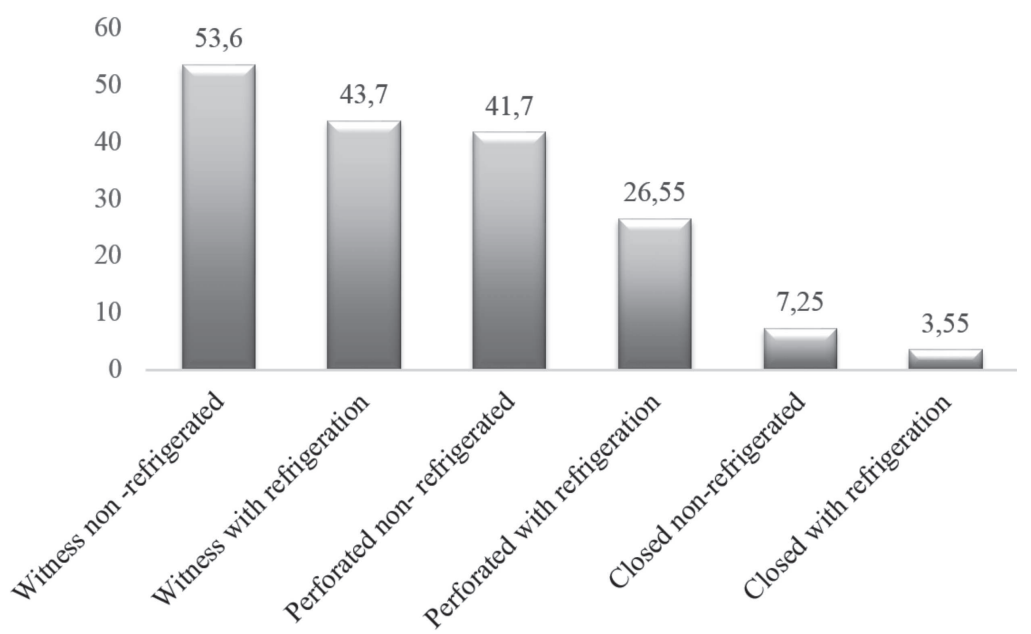

Figure 1: Percentage of fresh mass loss of crisp lettuce (Lactuca sativa L.) 'Brida', submitted to treatments: Control (without plastic packaging), Perforated plastic packaging and Closed plastic packaging, without and with refrigeration.

Table 1: Summary of variance analysis for the variables TSS (Total Soluble Solids), TTA (Total Titratable Acidity), pH, relative content of SPAD chlorophyll, chlorophyll A and B and carotenoids in crisp lettuce leaves (Lactuca sativa L.) 'Brida', submitted to treatments: Control (without plastic packaging); Plastic perforated packaging and Plastic packaging closed, without and with refrigeration

\begin{tabular}{|c|c|c|c|c|c|c|c|c|}
\hline & & $\begin{array}{c}\text { TSS } \\
\left({ }^{\circ} \text { Brix }\right)\end{array}$ & $\begin{array}{c}\text { TTA } \\
\text { (\% malic acid) }\end{array}$ & pH & $\begin{array}{c}\text { SPAD } \\
(\mu \mathrm{g})\end{array}$ & $\begin{array}{l}\text { Chlorophyll A } \\
\left(\mu g^{-1} \text { FM) }\right.\end{array}$ & $\begin{array}{c}\text { Chlorophyll B } \\
\left(\mu \mathrm{g} . \mathrm{g}^{-1} \text { FM }\right)\end{array}$ & $\begin{array}{c}\text { Carotenoids } \\
\left(\mu \mathrm{g} . \mathrm{g}^{-1} \mathrm{FM}\right)\end{array}$ \\
\hline SV & $\mathbf{L F}$ & AS & AS & AS & AS & AS & AS & AS \\
\hline Packaging $(\mathrm{P}) \mathrm{x}$ & 2 & $0.4654^{*}$ & $0.000037 *$ & $0.1702 *$ & $13.40^{\mathrm{ns}}$ & $0.0154^{\mathrm{ns}}$ & $0.0090^{\mathrm{ns}}$ & $0.1378^{\mathrm{ns}}$ \\
\hline Environment (E) & 1 & $0.0104^{\text {ns }}$ & $0.000003 *$ & $0.1426^{*}$ & $29.92 *$ & $0.0140^{\mathrm{ns}}$ & $0.0287^{\mathrm{ns}}$ & $0.0733^{\mathrm{ns}}$ \\
\hline$P \times E$ & 2 & $0.17544^{\mathrm{ns}}$ & $0.000003^{*}$ & $0.0832 *$ & $4.21^{\mathrm{ns}}$ & $0.0124^{\mathrm{ns}}$ & $0.0770^{\mathrm{ns}}$ & $0.4211^{*}$ \\
\hline Residues & 18 & 0.0854 & 0.000001 & 0.0175 & 4.71 & 0.0069 & 0.0472 & 0.0823 \\
\hline $\mathrm{CV} \%$ & & 55.74 & 29.57 & 3.44 & 14.49 & 27.47 & 39.58 & 68.23 \\
\hline Total & 23 & 56.48 & 29.57 & 3.85 & 66.73 & 27.52 & 39.74 & 68.94 \\
\hline
\end{tabular}

SV: source of variation; LF: level of freedom; AS: average square; P x E: Packaging and Environment; ${ }^{\text {ns: }}$ not significant. * significant at $5 \%$ by the Tukey test. 
was observed for all treatments except for the treatment of perforated plastic packaging with refrigeration (Table 2). It was also observed that only the treatment of closed plastic packaging with refrigeration presented statistical differences from the other treatments, being that this treatment presented a lower carotenoid value in relation to the other treatments (Table 2). According to Chitarra \& Chitarra (1990), carotenoid pigments may already be present, and are visible with the degradation of chlorophyll, or they may be synthesized with the degradation in the evolution of maturation (Paull \& Chen, 2003).

On the harvest day the SST content was $2.82^{\circ}$ Brix. When the treatments were compared with the SST value on the harvest day, a decrease in SST was observed for all treatments (Table 3). It is also verified that the treatment of closed plastic packaging presented a lower content of total soluble solids in relation to other treatments, independent of the storage environment. This decrease in the TSS content during the storage period is due the consumption of soluble solids, mainly sugar, which is the main source of substrate in respiration. Indeed, when a horticultural product is harvested at the optimum point of maturation, the sugar is used as a substrate in respiration (Kays, 1991). According to Neres et al. (2004), the alteration of contents in each type of packaging is related to the increase of total soluble solids concentration due to the water loss of the vegetable.

SPAD content on the harvest day was 18.1. At harvest, a decrease in the relative chlorophyll content was observed for the samples that were not conditioned in a refrigerated environment (Table 3). It was also verified that the treatments presented statistical differences, the treatment with the samples stored in refrigeration with temperature of $5^{\circ} \mathrm{C}$, presented a higher content of SPAD index due of low temperature to hinder the degradation of the chlorophyll, resulting in green leaves at the end of the sheet storage. Similar results were found by França et al. (2015), who attributed the preservation of chlorophyll in lettuce leaves due to refrigerated packaging.

According to Park et al. (1999), one of the main symptoms of senescence of leafy vegetables is the loss of green color, the temperature as the most influential factor for degradation of chlorophyll. Thus, the samples stored at a temperature of $\pm 5^{\circ} \mathrm{C}$ reduced the chlorophyll degradation process, contributing to the green color of the leaves.

The final storage time of the leaves (Table 4), was evaluated through the parameters of wilting, yellowing and the beginning of signs of deterioration, proving to be unfit for consumption. The samples of lettuce leaves submitted to the different types of treatments showed a shelf life of 6 to 20 days of storage.

The samples of lettuce leaves submitted to the closed plastic packaging with refrigeration presented a greater efficiency in relation to the conservation of leaves, during a period of 20 days, leading to a better water retention and decrease of respiration. The control treatment (without plastic packaging) was the one that presented a lower conservation of the leaves at 6 days, as a consequence of a greater loss of water and respiratory rate, leading to cause an aspect of yellowing and wilting in the leaves, then causing a great loss of quality.

According to Bolin et al. (1977) minimally processed lettuce when stored at $2{ }^{\circ} \mathrm{C}$ remained marketable for 26

Table 2: Average values of titratable total acidity, $\mathrm{pH}$ and carotenoids of crisp lettuce leaves (Lactuca sativa L.) of Brida cultivation, submitted to treatments: Control (without plastic packaging); Plastic perforated packaging and Plastic packaging closed, without and with refrigeration

\begin{tabular}{|c|c|c|c|}
\hline \multicolumn{4}{|c|}{ Titratable Total Acidity - TTA (\% malic acid) } \\
\hline \multicolumn{4}{|c|}{ Packaging } \\
\hline Environment & 1. Control & 2. Perforated & 3. Closed \\
\hline 1. Non-Refrigerated & $0.008450 \mathrm{Aa}$ & $0.007550 \mathrm{Aa}$ & $0.005475 \mathrm{Ab}$ \\
\hline 2. With Refrigeration & $0.008750 \mathrm{Aa}$ & $0.007300 \mathrm{Aa}$ & $0.003375 \mathrm{Bb}$ \\
\hline \multicolumn{4}{|c|}{ pH } \\
\hline & 1. Control & 2. Perforated & 3. Closed \\
\hline 1. No refrigeration & $5.90 \mathrm{Aa}$ & $5.79 \mathrm{Aa}$ & $5.92 \mathrm{Ba}$ \\
\hline 2. With refrigeration & $5.88 \mathrm{Ab}$ & $5.89 \mathrm{Ab}$ & $6.30 \mathrm{Aa}$ \\
\hline \multicolumn{4}{|c|}{ Carotenoids $\left(\mu{\left.\mathrm{g} . \mathrm{g}^{-1} \mathrm{FM}\right)}\right.$} \\
\hline & 1. Control & 2. Perforated & 3. Closed \\
\hline 1. Non-Refrigerated & $0.1680 \mathrm{Aa}$ & $0.1035 \mathrm{Aa}$ & $0.1707 \mathrm{Aa}$ \\
\hline 2. Refrigerated & $0.13335 \mathrm{Aab}$ & $0.2220 \mathrm{Aa}$ & $0.0327 \mathrm{Bb}$ \\
\hline
\end{tabular}

Averages followed by the same letter, uppercase and lowercase in the row do not differ statistically from each other by the Tukey Test, at $5 \%$ probability.

Rev. Ceres, Viçosa, v. 67, n.4, p. 247-250, jul/aug, 2020 
Table 3: Average values of total soluble solids content (TSS) and relative content of chlorophyll SPAD evaluated after the storage period of crisp lettuce leaves (Lactuca sativa L.) 'Brida' submitted to treatments: Control (without plastic packaging), Plastic perforated packaging and Plastic packaging closed, without and with refrigeration

\begin{tabular}{ll}
\hline \multicolumn{1}{c}{ Total Soluble Solids - TSS $\left({ }^{\circ}\right.$ Brix $)$} \\
\hline Packaging & \\
\hline 1. Control & $0.90 \mathrm{~A}$ \\
2. Perforated & $0.55 \mathrm{AB}$ \\
3. Closed & $0.44 \mathrm{~B}$ \\
\hline
\end{tabular}

\begin{tabular}{ll}
\hline \multicolumn{1}{c}{ Relative chlorophyll content SPAD (SPAD unit) } \\
\hline Environments & $16.5 \mathrm{~B}$ \\
1. No refrigeration & $18.7 \mathrm{~A}$ \\
\hline With cooling
\end{tabular}

Averages followed by the same letter do not differ statistically from each other by Tukey Test, at 5\% probability.

Table 4: Final storage time of the crisp lettuce (leaves of Lactuca sativa L.) 'Brida', submitted to treatments: Control (without plastic packaging), Perforated plastic packaging and Closed plastic packaging, without and with refrigeration

\begin{tabular}{lc}
\hline Treatments & Storage time (days) \\
\hline Control without refrigeration & 6 \\
Control with refrigeration & 7 \\
Packaging Perforated without refrigeration & 7 \\
Packaging Perforated with refrigeration & 7 \\
Packaging Closed without refrigeration & 7 \\
Packaging Closed with refrigeration & 20 \\
\hline
\end{tabular}

days when stored at a temperature of $10{ }^{\circ} \mathrm{C}$; its shelf life was 10 days. For this experiment, all refrigerated samples were kept at $\pm 5^{\circ} \mathrm{C}$. According to Cantwell (2000), in this temperature range the rate of respiration and deterioration are minimized.

The treatments in which the lettuce leaves samples were not conditioned in refrigeration showed a short postharvest life, providing high quantitative and qualitative losses of leaves (Kluge et al., 1998). According to Chitarra \& Chitarra (1990), the highest losses and the shortest storage periods occur due the storage of the product after harvesting in high temperature environments without refrigeration conditions.

\section{CONCLUSIONS}

1. The post-harvest conservation of hydroponic lettuces conditioned in closed plastic packaging with refrigeration had a better post-harvest conservation, and in the 20th day some leaves were in perfect state of conservation, due the efficiency in relation to the low loss of fresh mass, decreased respiration and degradation of chlorophyll in leaves.
2. Considering the physical-chemical parameters studied, there was a decrease in the acidity and respiratory rate in the treatments of closed plastic packaging with and without refrigeration, while the total soluble solids variable presented a decrease in all the treatments, due the physiological transformations that occur in plants such as maturation and deterioration.

3. The storage of lettuce leaves in a refrigerated environment with a temperature of $\pm 5^{\circ} \mathrm{C}$ kept the green coloration on the leaves of hydroponic lettuce.

\section{ACKNOWLEDGEMENTS}

We thank the laboratory of Hydroponics (LabHidro) and the Phytotron Laboratory for the materials assigned to the realization from work.

\section{REFERENCES}

AOAC - Association of Official Analytical Chemists (2002) Official methods of analysis of the Association of Official Analytical Chemistry. $17^{\mathrm{a}}$ ed. Washington, AOAC. $1115 \mathrm{p}$.

Ballou RH (2001) Gerenciamento da cadeia de suprimentos: planejamento, organização e logística empresarial. Porto Alegre, Bookman. 532 p.

Bezerra VS (2003) Pós-colheita de frutos. Macapá, Embrapa Amapá. $26 \mathrm{p}$.

Bolin HR, Stafford AD, King Jr AD \& Huxsoll CC (1977) Factors affecting the storage stability of shredded lettuce. Journal of Food Science, 42:1319-1321.

Bruinsma J (1963) The quantitative analysis of chlorophylls A and $B$ in plant extracts. Photochemistry and photobiology, 02:241-249.

Cantwell M (2000) Preparation and quality of fresh cut produce. In: $2^{\circ}$ Encontro Nacional sobre Processamento Mínimo de Frutas e Hortaliças, Viçosa. Anais, UFV. p.156-182.

Carvalho AV \& Lima LCO (2002) Qualidade de kiwi minimamente processados e submetidos a tratamentos com ácido ascórbico, ácido cítrico e cloreto de cálcio. Pesquisa Agropecuária Brasileira, 37:679-65.

Chitarra MIF \& Chitarra AB (1990) Pós-colheita de frutos e hortaliças: fisiologia e manuseio. Lavras, ESAL-FAEPE. 320p.

Chitarra MIF (1994) Colheita e qualidade pós-colheita de frutos. Informe Agropecuário, 17:08-18.

Chitarra MIF \& Chitarra AB (2005) Pós-colheita de frutos e hortaliças: fisiologia e manuseio. Lavras, UFLA. 785p.

Finger LF \& Vieira G (1997) Controle da perda pós-colheita de água em produtos hortícolas. Viçosa, UFV. 29 p.

Finger FL, Endres L, Mosquim PR \& Puiatti M (1999) Physiological changes during postharvest senescence of broccoli. Pesquisa Agropecuária Brasileira, 34:1565-1569.

França CFM, Ribeiro WS, Silva FC, Costa LC, Rêgo ER \& Finger FL (2015) Hydrocooling on postharvest conservation of butter lettuce. Horticultura Brasileira, 33:383-387.

Kays SJ (1991) Postharvest physiology of perishable plant products. New York, Van Nostrand Reinhold. 453p.

Kluge RA, Nachtigal JC, Fachinello JC \& Bilhalva AJ (1998) Fisiologia e manejo pós-colheita de frutas de clima temperado. Pelotas, Editora Universitária UFPEL. 163p.

Rev. Ceres, Viçosa, v. 67, n.4, p. 247-250, jul/aug, 2020 
Lichtenthaler HK (1987) Chlorophylls and carotenoids: pigment photosynthetic biomembranes. Methods in Enzymology, 148:362-385

Marin T, Montanucci JR, Benassi MT \& Yamashita F (2010) Embalagem ativa para alface americana (Lactuca sativa L.) minimamente processada. Semina: Ciências Agrárias, 31:653660.

Meirelles JCS (1998) Classificação de Alface. São Paulo, Horti \& Fruti. (Folder).

Moretti CL \& Mattos LM (2006) Processamento mínimo de alface crespa. Brasília, Embrapa Hortaliças. p.01-06. (Comunicado Técnico, 25).

Neres CRL, Vieira G, Diniz ER, Mota WF \& Puiatti M (2004) Conservação do jiló em função da temperatura de armazenamento e do filme de polietileno de baixa densidade. Bragantia, 63:431- 438 .

Oliveira LS, Silva TP, Ferreira APS, Pereira AM \& Finger FL (2015) Efeito do hidroresfriamento na conservação pós-colheita de coentro. Horticultura Brasileira, 33:448-452.

Park KW, Kang HM, Yang EM \& Jung JC (1999) Effects of film packaging and storage temperature on the quality of parsley in modified atmosphere storage. Acta Horticulturae, 483:291-298.

Paschoalino JE (1997) Hortaliças acidificadas em conserva: riscos e cuidados. Campinas, Instituto de Tecnologia de Alimentos. p.01-07. (Informativo Fruthotec, 2).
Paull RE \& Chen CC (2003) Postharvest physiology, handling, and storage of Pineapple. In: Bartholomew DP, Paull RE \& Rohrbach KG (Eds.) The Pineapple: Botany, Production and Uses. Wallingford, CABI Publishing. p.253-279.

Rickman JC, Barrett DM \& Bruhn CM (2007) Review Nutritional comparison of fresh, frozen and canned fruits and vegetables. Part 1. Vitamins C and B and phenolic compounds. Journal of the Science Food and Agriculture, 87:930-944.

Rinaldi MM, Benedetti BC \& Calore L (2005) Efeito da embalagem e temperatura de armazenamento em repolho minimamente processado. Food Science and Technology, 25:480-486.

Rodrigues IN, Lopes MTG, Lopes R, Range AS \& Miracles CP (2007) Evaluation of cultivars of crisp lettuce for the region of Manaus. In: $47^{\text {th }}$ Brazilian Congress on Olericulture, Porto Seguro. Abstracts, ABH. CD-ROM.

Rosa OO (2002) Microbiota associada a produtos hortícolas minimamente processados comercializados em supermercados. Tese de Doutorado. Universidade Federal de Lavras, Lavras. 202p.

Shepherd AW (1993) A guide to marketing costs and how to calculate them. Rome, FAO/ Agricultural Support System Division/ Marketing and Rural Finance Service. 23 p.

Soares I (2002) Alface: cultivo hidropônico. Fortaleza, Editora UFC. $50 \mathrm{p}$. 